\title{
İzmir İli Tarım Topraklarının Verimlilik Durumları ile Mikroelement Kapsamlarının Belirlenerek Haritalanması
}

\author{
Nejat ÖZDEN ${ }^{1, *}$ İdris USLU' Ömer SÖKMEN' Faruk METINOĞLU' \\ 'Uluslararası Tarımsal Araștırma ve Eğitim Merkezi Müdürlüğü, Menemen / İzmir
}

\begin{abstract}
*Sorumlu yazar e-mail (Corresponding author e-mail): nejat.ozden@tarimorman.gov.tr
Geliș tarihi (Received) : 10.03.2020

Kabul tarihi (Accepted): 02.10.2020

DOI: 10.21657/topraksu.701590
\end{abstract}

\section{Öz}

Araștırma, İzmir ili tarım topraklarının verimlilik ve mikroelement kapsamlarını belirlemek, CBS tekniği kullanılarak veri tabanı ve dağılım haritalarını olușturmak amacıyla 2014-2017 yıllarında yürütülmüștür. Araștırma kapsamında, tarım alanlarını temsil edecek șekilde $2.5 \mathrm{~km} \times 2.5 \mathrm{~km}$ aralıklarla $0-20 \mathrm{~cm}$ toprak derinliğinden 502 toprak örneği alınmıștır. Alınan toprak örneklerinde; bünye, pH, EC, kireç, organik madde ile ekstrakte edilebilir fosfor, potasyum, demir, bakır, çinko ve mangan analizleri yapılmıștır. Toprak analiz sonuçları, belli kriterlere göre sınıflandırılarak, besin maddelerinin eksiklik, yeterlilik veya fazlalık seviyeleri belirlenmiștir. Araștırma sonucuna göre, İzmir ili tarım topraklarının \%55.18'inin kumlu tın-kumlu killi tın bünyede, \%49.60'ının orta alkali, \%42.03'ünün çok hafif tuzlu, \%57.17'sinin kireçsizçok az kireçli, \%55.98'inin ise çok az organik maddeye sahip olduğu saptanmıștır. Alınabilir elementler bakımından \%28.09'unda fosfor yetersiz, ekstrakte edilebilir elementler bakımından \%47.21'sinde potasyum zengin, \%90.84'ünde demir, \%96.61'inde mangan yüksek, \%44.42'sinde çinko, \%69.92'sinde bakır orta seviyede bulunmuștur. Toprak parametrelerinin sınıflandırılmasından sonra CBS kapsamında veri tabanı olușturulmuș ve IDW yöntemi kullanılarak toprak dağılım haritaları üretilmiștir.

Anahtar Kelimeler: IDW, İzmir, mikro bitki besin elementi, toprak verimliliği, veri tabanı

\section{Determining and Mapping the Fertility and Microelement Scopes of the Agricultural Soils of İzmir Province}

\begin{abstract}
This research was carried out to determine the fertility and microelement scopes of the agricultural soils of İzmir province and to create a database and distribution maps (pin maps) by using geographic information systems technique between 2014-2017. Within the scope of the research, a total of 502 soil samples, representing agricultural areas, were taken from 0-20 cm soil depth with $2.5 \mathrm{~km}$ x $2.5 \mathrm{~km}$ grid intervals. In soil samples taken; texture, $\mathrm{pH}$, EC, lime, organic matter and extractable phosphorus, potassium, iron, copper, zinc and manganese analyzes were performed. Soil analysis results were classified according to certain criteria and deficiency, adequacy or excess levels of nutrients were determined. After the classification of soil parameters, a database was created within the scope of GIS and soil distribution maps were produced via Inverse Distance Weighted method. According to the results it was found out that, 55.18\% agricultural soils of İmir was sandy-loamy, 49.60\% was mildly alkaline, $42.03 \%$ was slightly saline, $57.17 \%$ was non calcareous-slightly calcareous, 55.98\% had minimal organic matter. In terms of available elements, $28.09 \%$ did not have enough phosphorus, in terms of extractable elements $47.21 \%$ had high potassium, $90.84 \%$ had high levels of iron, $96.61 \%$ had high levels of manganese, $44.42 \%$ had zinc and $69.91 \%$ had medium levels of cooper.
\end{abstract}

Keyword: Database, İzmir, micro plant nutrient element, soil fertility, IDW 


\section{Gíriș}

Tarım sürdürülebilmesi için, öncelikle bu alanların özelliklerinin en iyi șekilde tanımlanması, bunun için de toprakların fiziksel ve kimyasal özelliklerinin belirlenmesi gereklidir. Tarım alanlarının özelliklerinin belirlenip güncelleștirilerek bir veri tabanı olușturulması, toprak kaynaklarının doğru kullanımına yönelik yeni araștırma projeleri için de ön bilgiler sağlayacaktır. Coğrafi koordinatları belli toprak örnekleri üzerinde yapılacak analizler sonucunda, belirlenen özelliklerin zaman içindeki değișimleri de takip edilerek, tarım alanlarındaki olumsuz değișmeler kontrol altına alınabilecektir. Bilișim teknolojisinde hızlı gelișmelere tanıklık eden çağımızda, her türlü bilgiyi toplamak, ișlenebilir hale getirmek ve bilgiyi toplum yararına paylașmak en önemli değerler olmuștur. Bu anlamda, tüm bilgilerin \%80' ini olușturan harita bilgilerinin elektronik ortamda yönetilmesinde etkin bir araç haline gelen Coğrafi Bilgi Sistemleri (CBS), bugünün ve geleceğin en önemli bilgi teknolojisi sayılmaktadır (Özten, 2006). Farklı niteliklere sahip toprakların en üretken șekilde kullanılması amaçlandığında çeșitli kullanım türlerinin gereksinimleri dikkate alınarak bir planlamaya gidilmesi zorunludur. Bu nedenle çok karmașık bir yapıya sahip olan toprakların da bitkiler, hayvanlar ve diğer objeler gibi sınıflandırılması zorunluluğu vardır (Roberts, 1979).

İzmir ilinde yürütülen bu araștırma ile tarım yapılan toprakların verimlilik ve mikroelement kapsamlarının belirlenmesi, belirlenen bu toprak özelliklerinde sonradan olușacak değișimlerin izlenebilmesini sağlayacak güncel toprak veri tabanlarının olușturulması ve haritalanması amaçlanmıștır.

\section{MATERYAL VE YÖNTEM}

\section{Materyal}

Araștırma örnek alanı olarak İzmir ili tarım toprakları seçilmiștir. Yüzölçümü 12086 km² olan İzmir ili batıda Ege Denizi, kuzeyde Balıkesir, doğuda Manisa, güneyde de Aydın illeriyle sınırıdır (Șekil 1). Araștırmanın ana materyalini olușturan İzmir ili topraklarının \% 28.5'ini tarım alanları olușturmaktadır. Toplam $3.450 \mathrm{~km}^{2}$ tarım arazilerinin; \%41.4'ü tarla, \%28.2'si zeytin, \%10.9'u sebze, \%9.8'i meyve ve \%3.7'si bağ alanıdır.

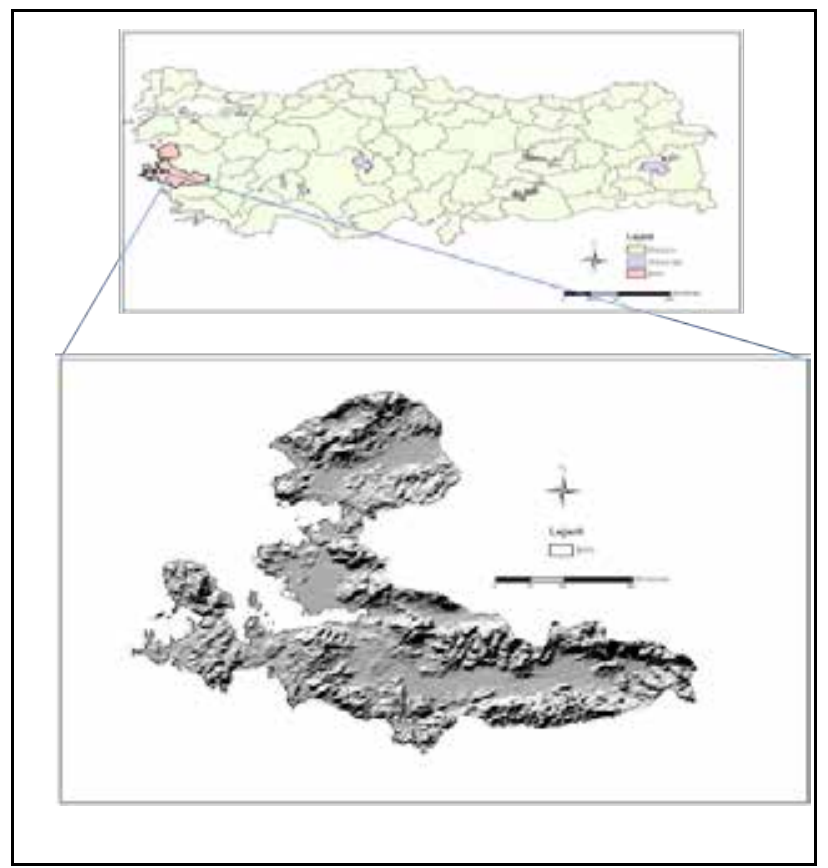

Șekil 1. Araștırma alanı

Figure 1. Research area

\section{Yöntem}

Toprak örnekleme alanlarının belirlenerek örneklerin alınması

Araștırmada alınacak toprak örneği sayısını tespit etmek için, Mülga Köy Hizmetleri Genel Müdürlüğü tarafından sayısal ortama aktarılan 1/25000 ölçekteki toprak haritalarından; sulu tarım, kuru tarım, bağ, bahçe, zeytin, turunçgiller vb. tarım yapılan alanlar dikkate alınarak çalıșma alanı belirlenmiștir. Türkiye haritası üzerinde $2.5 \mathrm{~km}$ x 2.5 km'lik gridler olușturulmuș ve tarım alanlarına düșen noktalar seçilerek, İzmir ili için 502 örnek sayısı tespit edilmiștir (Șekil 2).

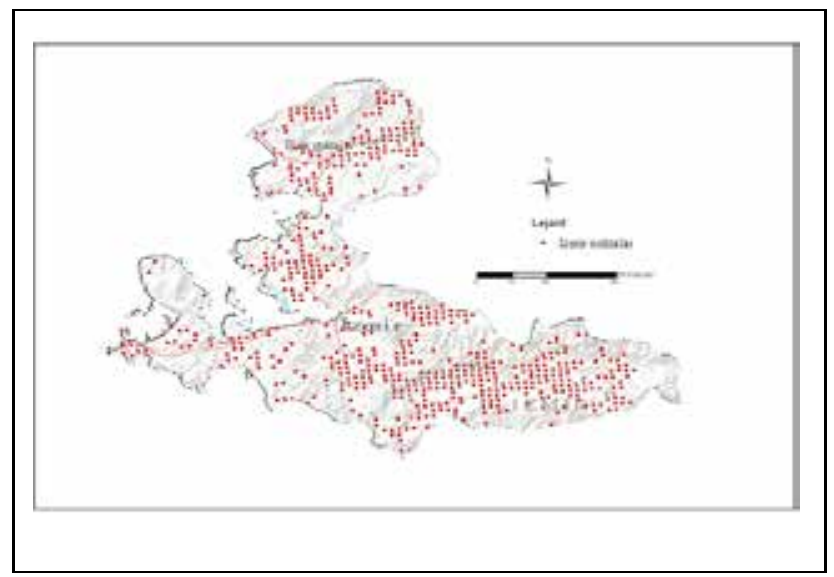

Şekil 2. $2.5 \mathrm{~km} \times 2.5 \mathrm{~km}$ grid sistemine göre toprak örneklerinin alındığı lokasyonlar

Figure 2. Locations of the soil samples taken according to $2.5 \mathrm{~km} \times 2.5 \mathrm{~km}$ grid system 
Koordinatları önceden belirlenmiș olan noktalara GPS ile gidilerek, toprak örnekleri 0-20 $\mathrm{cm}$ derinlikten paslanmaz çelik kürek ile alınmıș ve polietilen torbalara konularak örnek numarası yazılmak suretiyle etiketlenmiștir.

\section{Toprak örneklerinde laboratuvar analizleri}

Laboratuvara getirilen toprak örnekleri, temiz ambalaj kağıtlarına serilerek, taș ve bitki parçacıkları ayıklanacak ve havada kurumaya bırakılacaktır. Kuruyan topraklar tahta tokmaklarla dövülerek 2 mm'lik çelik elekten geçirilmiș, analizler için gerekli miktarlar polietilen kutulara konularak etiketlenmiș, kalan toprak örnekleri usulüne uygun olarak arșivlenmiștir. Araștırma alanından alınan toprak örneklerinin; kum, kil ve silt yüzdeleri, Bouyoucos hidrometre yöntemiyle (Bouyoucos, 1951); toprak reaksiyonu $(\mathrm{pH})$, hazırlanan saturasyon çamurunda cam elektrotlu pH metre ile ölçülerek (Richards, 1954) tayin edilmiștir. Toprakların elektriksel iletkenlik (EC) değerleri, saturasyon çamurundan çıkartılan ekstrakta kondaktivite cihazı ile ölçülmesiyle (Richards, 1954); kireç (CaCO3) içerikleri, Scheibler kalsimetresi ile volümetrik metotla (Çağlar, 1949); organik madde, modifiye Walkley-Black yaș yakma yöntemiyle (Nelson ve Sommers, 1982) saptanmıștır. Alkalin ve nötr karakterli toprakların alınabilir $\mathrm{P}$ içerikleri, Olsen yöntemine göre (Olsen vd., 1954), ekstrakte edilebilir $\mathrm{K}, \mathrm{Fe}, \mathrm{Cu}, \mathrm{Zn}$ ve $\mathrm{Mn}$ değerleri, toprak örneklerinin $1 \mathrm{~N}$ amonyum asetat $(\mathrm{pH}=7.0)$ çözeltisi ile ekstrakte edilmesiyle (Soil Survey Staff, 1992) belirlenmiștir.

\section{Veri tabanı olușturma ve haritalama}

Projenin üçüncü așamasında; birinci ve ikinci așama sonuçlarında elde edilen veriler CBS kapsamında değerlendirilmiș, analiz edilmiș, veri tabanı olușturulmuș ve haritalanması ișlemleri gerçekleștirilmiștir. Toprak analizleri sonucunda elde edilen bilgiler, arazi çalıșmaları sırasında elde edilen konumsal bilgilerle ilișkilendirilmek suretiyle her gözlem noktasına ait analiz sonuçlarını içeren dosyalar elde edilmiștir. Öznitelik tablolarında bulunan ve her bir gözlem noktasına ait toprak analiz sonuçlarını içeren veriler ayrı ayrı ele alınarak CBS' nin analiz fonksiyonlarından yararlanılarak değerlendirilmiștir.

Noktasal özellikte olan toprak analiz sonuçları, ölçülmüș değerlerden yola çıkarak ölçülmemiș noktaların tahmin edilmesi için kullanılan "InversDistanceWeighting (IDW)" doğrusal olmayan enterpolasyon teknikleri kullanılarak haritalandırımıștır. IDW; bilinen örnek noktalara ait değerlerin yardımıyla örneklenmeyen noktalara ait hücre değerlerinin belirlenmesi için kullanılan bir enterpolasyon tekniğidir. İlgili hücreden uzaklașan çeșitli noktalar gözetilerek ve mesafedeki artıșa bağlı olarak hücre değeri hesap edilir. Tahmin edilen değerler, komșu civardaki noktaların uzaklığı ve büyüklüğünün bir fonksiyonu olup, mesafenin artması ile tahmini yapılacak hücre üzerindeki önem ve etki azalır. Bu yöntemde verilen genel dağılımı, eğilimi, anizotropi ve kümelenmesi gibi özellikler incelenmektedir. Verilerin sadece yerel olarak değerlendirilip, karșılaștırılması yapılmaktadır. IDW, deterministik bir yöntemdir (Korkmaz vd., 2008; Doğan vd., 2013). Ağırlıklı hareketli ortalama enterpolasyon için yaygın kullanılan bir yaklașımdır. Farklı ağırlıklı fonksiyonların çeșitleri kullanılmıs fakat IDW, CBS sistemlerindeki en ortak form olmustur. IDW tam bir ara değer üreticisidir. Öyle ki verilerin değerlerini pekiștirir. IDW tahmincisi așağıdaki gibidir (Loyd, 2007; Demircan vd., 2011);

Tahminlerin yapıldığı $X_{0}$ lokasyonu, komșu $z\left(X_{0}\right)=\frac{\sum_{1=1}^{n} z\left(X_{i}\right) \cdot d_{i 0}^{-r}}{\sum_{i=1}^{n} d_{i 0}^{-r}}$

Ölçümleri n'nin bir fonksiyonudur $\left(z\left(X_{0 i}\right)\right.$ ve $i=1,2, \ldots, n) ; r$ gözlemlerin her birinin atanmıș aralığını belirleyen üstür ve d gözlem lokasyonu $X i$ ile tahmin lokasyonu $X_{0}^{\prime} 1$ ayıran mesafedir. Üs büyüdükçe, tahmin lokasyonundan uzak mesafedeki gözlemlerin atanmıș ağırlığı küçülür. Üssün artması, tahminlerin en yakınındaki gözlemlere çok benzediğini gösterir (Demircan vd., 2011 ). Matematiksel formüller yukarıda açıklandığı șekilde olup, CBS yazılımı olan ArcGIS ortamında hesaplanmıș ve haritalar üretilmiștir.

\section{BULGULAR VE TARTIȘMA}

İzmir ili tarım topraklarından alınan toprak örneklerinin verimlilik ve mikroelement analiz sonuçlarına ait tanımlayıcı istatistikler Cizelge 1 ve 2'de verilmiștir. Çarpıklık normal dağılıșta simetrikliğin bozulma derecesi olarak bilinmektedir. Çizelge 1 ve 2 'de verilen çarpıklık katsayıları incelendiğinde; kum, silt, kil pH, organik madde dıșındaki özelliklerin normal dağılımdan uzak pozitif dağılımlar gösterdiği saptanmıștır. Pozitif çarpıklık katsayıları, incelenen toprak özelliklerinin sola doğru bir asimetrik yapı ile normal dağılımdan uzaklaștığını göstermektedir. Bu durum, birçok 
Çizelge 1. İzmir ili tarım topraklarının verimlilik yönünden tanımlayıcı istatistikleri

Table 1. Descriptive statistics of izmir agricultural lands in terms of fertility

\begin{tabular}{lccccccccc}
\hline & Kum (\%) & Silt (\%) & $\begin{array}{c}\text { Kil } \\
(\%)\end{array}$ & $\mathrm{pH}$ & $\begin{array}{c}\mathrm{EC} \\
\left.(\mathrm{dSm})^{-1}\right)\end{array}$ & $\begin{array}{c}\mathrm{CaCO}_{3} \\
(\%)\end{array}$ & $\begin{array}{c}\text { Org. Madde } \\
(\%)\end{array}$ & $\begin{array}{c}\text { Alın. P } \\
\left(\mathrm{mgkg}^{-1}\right)\end{array}$ & $\begin{array}{c}\text { Alın. K } \\
\left(\mathrm{mgkg}^{-1}\right)\end{array}$ \\
\hline En Düșük & 14.40 & 4.00 & 1.28 & 4.08 & 0.18 & 0.01 & 0.66 & 1.04 & 30.10 \\
En Yüksek & 94.20 & 54.00 & 57.04 & 8.62 & 12.33 & 41.96 & 4.81 & 167.39 & 2666.20 \\
Ortalama & 57.89 & 24.16 & 17.95 & 7.20 & 1.51 & 5.26 & 1.94 & 21.67 & 299.10 \\
Basıklık & -0.34 & 0.45 & 0.91 & -1.05 & 3.14 & 2.28 & 1.01 & 2.46 & 3.91 \\
Çarpıklık & -0.54 & 0.18 & 0.31 & 1.30 & 13.33 & 5.03 & 1.01 & 8.74 & 25.28 \\
Ortanca & 60.40 & 24.00 & 15.18 & 7.41 & 0.95 & 1.17 & 1.82 & 14.23 & 227.25 \\
Std. Sapma & 16.35 & 8.52 & 11.46 & 0.77 & 1.55 & 8.51 & 0.75 & 2.22 & 2.69 \\
Varyans & 267.17 & 72.54 & 131.38 & 0.60 & 2.39 & 72.43 & 0.56 & 494.32 & 269.15 \\
Var. Kat. & 28.24 & 35.26 & 63.84 & 10.69 & 102.65 & 161.79 & 38.66 & 10.24 & 0.90 \\
\hline
\end{tabular}

Çizelge 2. İzmir ili tarım topraklarının mikroelement yönünden tanımlayıcı istatistikleri

Table 2. Descriptive statistics of izmir agricultural lands in terms of microelements

\begin{tabular}{lccccc}
\hline & \multicolumn{4}{c}{ Ekstrakte Edilebilir Elementler $\left(\mathrm{mgkg}^{-1}\right)$} \\
En Düșük & $\mathrm{Fe}$ & $\mathrm{Cu}$ & $\mathrm{Zn}$ & $\mathrm{Mn}$ & $\mathrm{B}$ \\
En Yüksek & 2.04 & 0.01 & 0.07 & 2.20 & 0.02 \\
Ortalama & 269.70 & 30.20 & 19.14 & 299.60 & 4.30 \\
Basıklık & 29.95 & 2.35 & 1.44 & 28.98 & 0.55 \\
Çarpıklık & 2.93 & 3.85 & 4.25 & 3.48 & 3.80 \\
Ortanca & 10.64 & 19.80 & 25.97 & 15.56 & 22.31 \\
Std. Sapma & 16.35 & 1.31 & 0.86 & 16.29 & 0.45 \\
Varyans & 37.69 & 3.31 & 1.85 & 35.75 & 0.44 \\
Değ. Kat. & 1420.00 & 10.94 & 3.44 & 1278.00 & 0.20 \\
\hline & 125.84 & 140.85 & 128.47 & 123.36 & 80.00 \\
\hline
\end{tabular}

toprak özelliklerine ait değișkenlik katsayılarının yüksek bulunmasıyla da desteklenmektedir. Wilding (1985) ile Mulla and Mc Bratney (2000) toprak özelliklerindeki değișimlerin açıklanmasında önemli bir gösterge olarak kabul edilen değișkenlik katsayısını, aldığı değerlere göre düșük $(<\% 15)$, orta (\%15-35) ve yüksek (>\%35) olarak sınıflandırmaktadırlar.

Bu araștırmada, incelenen toprak özelliklerinde $\mathrm{pH}$, alınabilir fosfor ve ekstrakte edilebilir potasyumun düșük, kum bünyenin orta, diğer toprak özelliklerinin ise yüksek değișkenliğe sahip olduğu, en fazla değișkenlik gösteren toprak özelliğinin ekstrakte edilebilir $\mathrm{Cu}$ (\%140.85) olduğu görülmektedir (Çizelge 2). Literatürde birçok araștırmacı toprak özelliklerinin değișkenlik katsayısına göre düșük, orta ve yüksek değișkenlikler gösterdiğini (Erșahin 1999; Sağlam 2008; Özyazıcı vd. 2011; Sağlam 2013; Dengiz vd. 2015) bildirmektedir.
Toprağın fiziksel özellikleri, toprağın görülebilen veya hissedilebilen özellikleri olarak tanımlanabilir. Topraktabulunan kum, kilvetın gibi parçacıklarınoranı toprağın bünyesini olușturur. Verimlilikte toprağın bünyesinin etkisi büyüktür. Toprak bünyesinin incelmesiyle bitkiler için gerekli olan besin maddeleri, ana materyalin yapısı göz önüne alındığında daha yüksek düzeyde olduğu bilinmektedir. Araștırma alanı topraklarının kum içeriği \%14.40-94.20, silt içeriği \%4.00-54.00 ve kil içeriği ise \%1.28-57.04 arasında değișmekte olup \%55.18'inin kumlu tın-kumlu killi tın bünyede olduğu belirlenmiștir (Șekil 3, 4 ve 5). Kaba bünyeli topraklarda hem azot eksikliği hem de ürün miktarı düșük çıkabilir. Araștırma topraklarının genel olarak yarısı hafif kaba bünyeli olduğu göz önüne alındığında, toprakların organik madde miktarının arttıılıması gerekir. Topraksu (1 983)'e göre saturasyon yüzdesine göre yapılan sınıflandırmada İmir ili tarım topraklarının \%52.9'u tınlı, \%40.8'i killi tınlı, \%5.8'i killi ve \%0.5'i kumlu bünyeye sahiptir. 


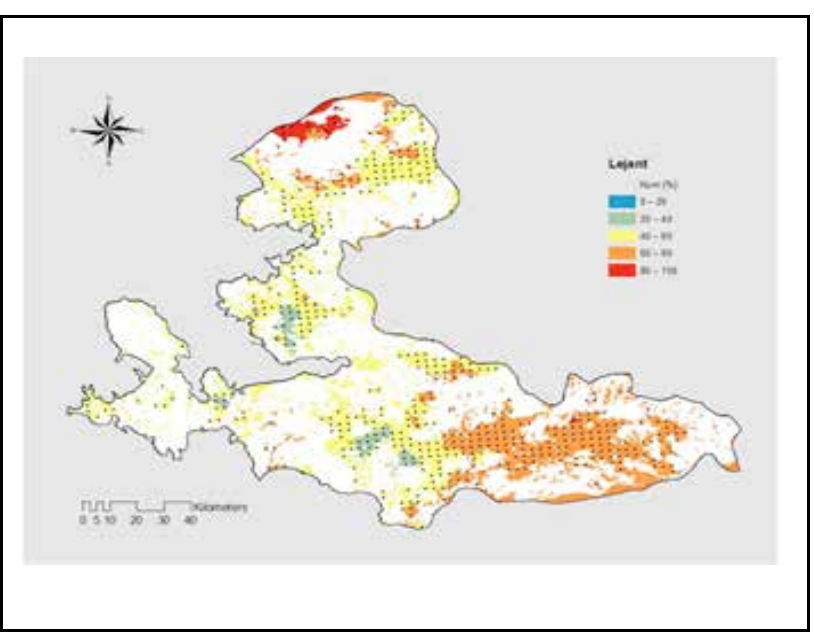

Șekil 3. İzmir ili tarım topraklarının kum değerlerine ait değișim haritası

Figure 3. Change map of the sand levels of Izmir agricultural lands

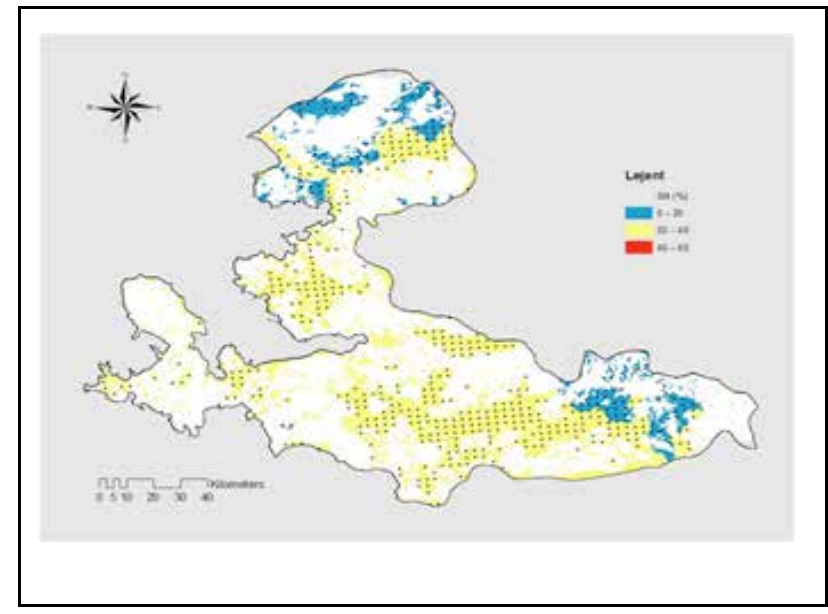

Șekil 4. İzmir ili tarım topraklarının silt değerlerine ait değișim haritası

Figure 4. Change map of the silt levels of izmir agricultural lands

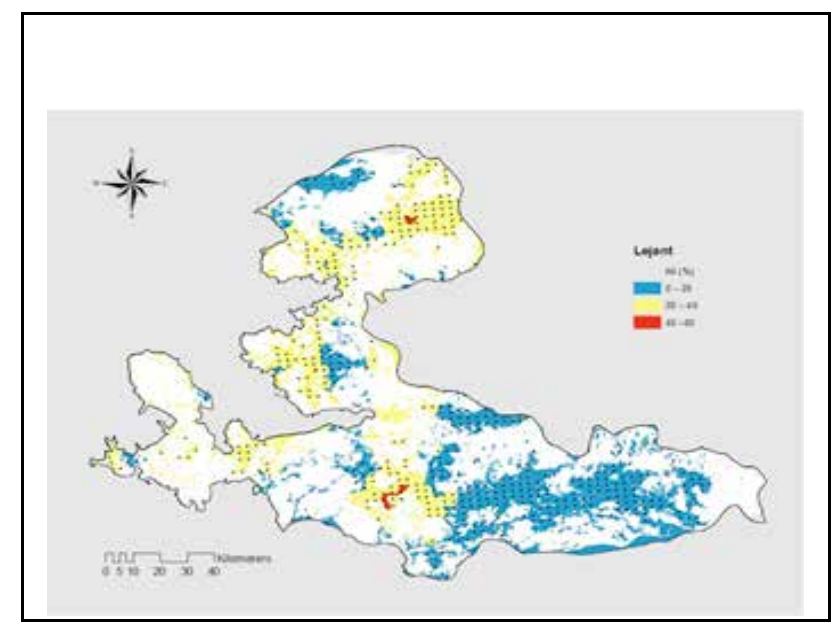

Șekil 5. İzmir ili tarım topraklarının kil değerlerine ait değișim haritası

Figure 5. Change map of the clay levels of Izmir agricultural lands
Toprakta bitki besin elementlerinin alınabilirliği ve toprak mikrorganizmalarının faaliyetleri, birçok etkenin yanı sıra toprak $\mathrm{pH}$ 'sı ile yakından ilișkilidir (Çengel, 2006). İncelenen topraklarda $\mathrm{pH}$ 4.08-8.62 arasında değișmekte olup, toprakların \%49.60'ının orta alkali karakterde olduğu saptanmıștır (Șekil 6). pH derecesi orta alkali olan araștırma alanı topraklarında alkaliliğin nedenlerine göre, drenaj kanalları açma, su ile yıkama, toprağa kükürt ve jips verme gibi yöntemlerle toprak reaksiyonu iyileștirilebilir. Topraksu (1 983)'e göre İzmir ili tarım topraklarının \%31.1'i asit, \%60.8'i nötr, \%7.1'i ise alkali reaksiyona sahiptir.

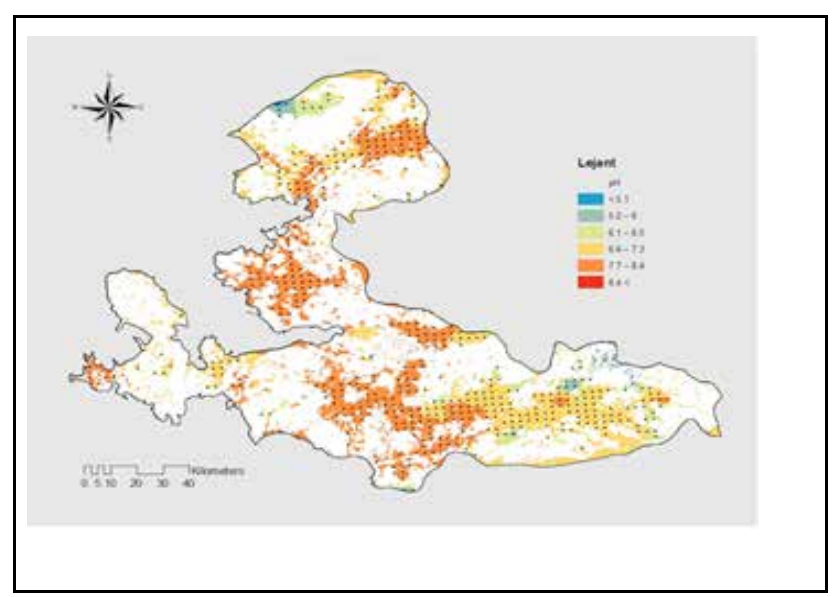

Șekil 6. İzmir ili tarım topraklarının pH değerlerine ait değișim haritası

Figure 6. Change map of the clay levels of izmir agricultural lands

Bitki besin maddelerinin azlığı kadar fazlalığı da bitkilere zararlı olmakta ve belirli bir düzeyden fazla olması halinde bitkiler çimlenememekte, kurumakta ve ölmektedirler. Bunun en belirgin örneği toprağın toplam eriyebilir tuz miktarının fazla olduğu durumlarda görülür. Toprakta tuz miktarı $100 \mathrm{~g}$ toprakta 150 mg'ın üzerine çıktığı zaman bitki gelișimini engelleyen etkiler yapmaya bașlar (Altınbaș vd., 2004). Araștırma alanı topraklarında EC 0.18-12.33 dSm-1 arasında değișmekte olup, toprakların \%42.03'ünün çok hafif tuzlu olduğu bulunmuștur (Șekil 7). Topraksu (1983)'e göre İzmir ili tarım topraklarının \%92.2'i tuzsuz, \%3.3'ü hafif tuzlu, \%0.4'ü orta tuzlu ve $\% 0.1$ 'i ise çok tuzludur. Eyüpoğlu (1999), Türkiye topraklarının verimlilik durumu üzerine yaptığı çalıșmada, İzmir ili topraklarının \%96.2'sinin tuzsuz olduğunu saptamıștır. 


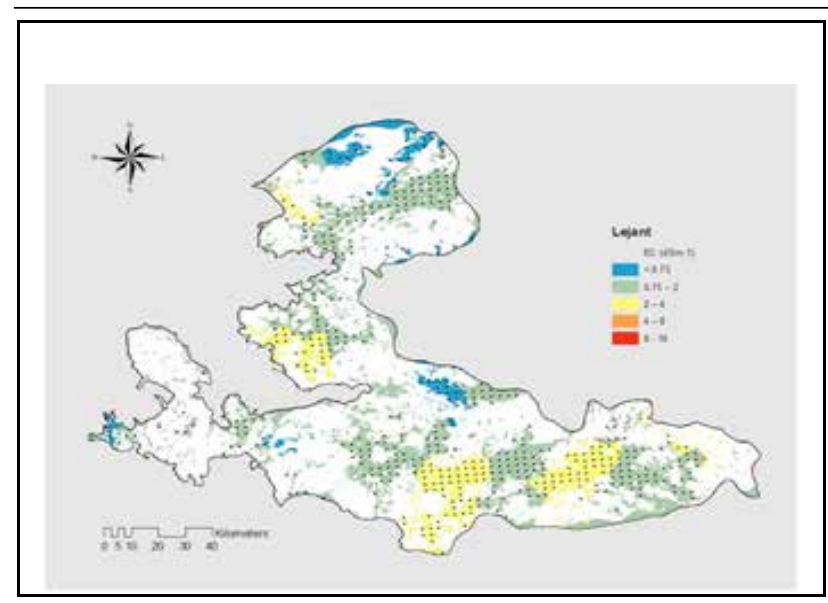

Șekil 7. İzmir ili tarım topraklarının EC değerlerine ait değıșim haritası

Figure 7. Change map of the EC levels of Izmir agricultural lands

Kireç kil, kum ve humus toprağın katı kısmını olușturan dört ana unsurdur. Temel unsurlardan olan kireç, humus ve killerin birlikteliğini sağlar. Topraklarda kireç genellikle kalsiyum karbonat veya dolomit kireci halinde bulunur. Topraktaki kireç yağıșlar ve sulama suyunun eritme etkisi ile çözünerek kalsiyum ve karbonat veya bikarbonat șeklinde iyonlara ayrılır. Bu iyonların toprak ortamında veya sulama suyunda fazla bulunması bitki beslenmesi bakımından (özellikle demir, çinko ve fosfor elverișliliği) büyük problemler meydana getirmektedir. Araștırma alanı topraklarında kireç \%0.01-41.96 arasında değișmekte olup, toprakların yarıdan fazlasının (\%57.17) kireçsiz, çok az kireçli olduğu tespit edilmiștir (Șekil 8). Topraksu (1983)'e göre İzmir ili tarım topraklarının \%59.4'ü az kireçli, \%17.7'si kireçli, \%13.7'si orta kireçli, \%4.9'u fazla kireçli ve \%4.3'i ise çok fazla kireçli olarak saptanmıștır.

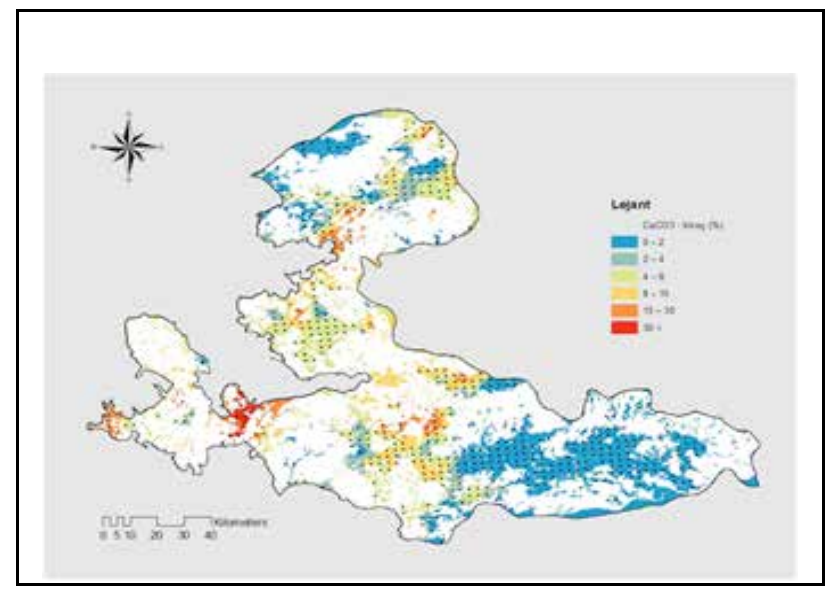

Șekil 8. İzmir ili tarım topraklarının kireç $\left(\mathrm{CaCO}_{3}\right)$ değerlerine ait değișim haritası

Figure 8. Change map of the lime levels $\left(\mathrm{CaCO}_{3}\right)$ of izmir agricultural lands
Organik madde bitkiler için önemli bir besin maddesi kaynağıdır. Topraktaki azotun \%90'dan fazlasının toprak organik maddesinde bulunması nedeniyle, organik maddenin besin kaynağı ișlevi ile azot açısından ayrı bir önem tașımaktadır (Altınbaș vd., 2004). Araștırma alanı topraklarında organik madde \%0.66-4.81 arasında değișmekte olup, toprakların \%55.98'inde az seviyede organik madde içerdiği saptanmıștır. (Șekil 9). Organik madde toprak verimliliğini, toprakların fiziksel ve kimyasal özelliklerini etkileyen en önemli unsurlardan biridir. Azaltılmıș toprak ișleme, zamanında ve yeterli azotlu gübreleme, yeșil gübreleme ya da yanmıș ahır gübresi uygulamalarıyla toprağın organik madde miktarı artırılabilir. Topraksu (1983)'e göre İzmir ili tarım topraklarının \%15.9'unda organik madde çok az, \%50.0'sinda az, \%25.5'inde orta, \%6.4'ünde iyi ve $\% 2.2$ 'sinde ise yüksek olarak bulunmuștur.

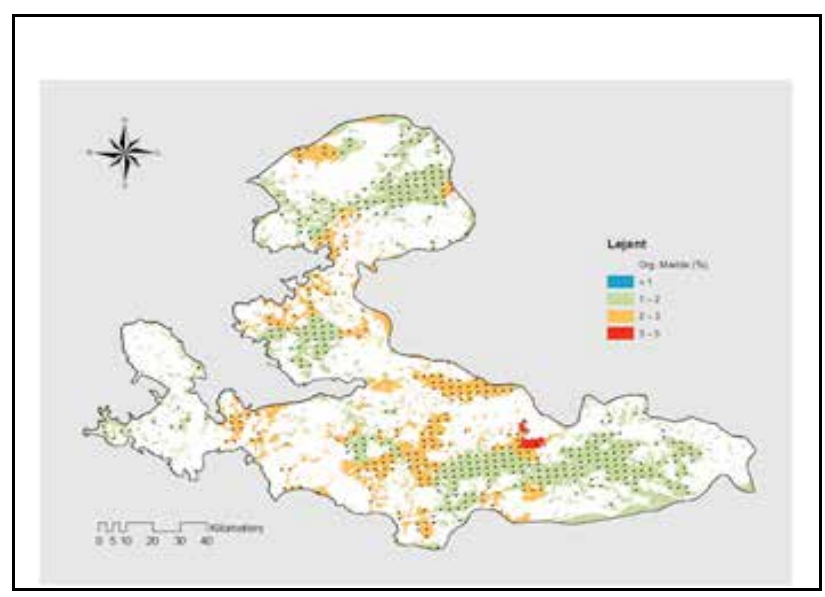

Șekil 9. İzmir ili tarım topraklarının organik madde değerlerine ait değișim haritası

Figure 9. Change map of the organic matter levels of Izmir agricultural lands

Toprak fosforunun en önemli kaynağı primer minerallerdir. Primer minerallerin așınma ve parçalanması ile serbest hale geçen fosforun bitkiler tarafından alınması ve asimilasyonu ile fosfor organik maddeye bağlanır. Organik materyalin çeșitli dönüșümler sonundan toprağa geçmesi ile toprakta organik fosfor fraksiyonu olușur. Bu formdaki fosforun bitkiye yarayıșlı hale geçmesi ancak organik maddenin parçalanması ile olasıdır. Ancak, organik fosfor bileșikleri yavaș parçalanan bileșiklerdir. Sıcaklık ve $\mathrm{pH}$ toprak organik fosforunun parçalanmasında önemli iki etmendir. Yapılan çalıșmalarda toprak pH'sı arttıkça organik fosforun azaldığı belirlenmiștir (Thompson, 
1950). Bitki açısından fosfor kök gelișimi, bitki olgunlașması, erken tohum teșekkülü, döllenme ile hastalık ve zararlılara karșı direnci arttırdığından büyük önem arz eden bir besin elementidir (Bilen ve Sezen, 1993). Incelenen topraklarda bitkiler tarafından alınabilir P $1.04-167.39 \mathrm{mgkg}^{-1}$ arasında değișmekte olup, toprakların \%28.09'unda P'nin yetersiz olduğu belirlenmiștir (Șekil 10). Topraksu (1983)'e göre Izmir ili tarım topraklarının \%25.1'inde $\mathrm{P}_{2} \mathrm{O}_{5}$ çok az, \%25.6'sında az, \%17.7'sinde orta, $\% 10.9$ 'unda yüksek, \%20.7'sinde ise çok yüksek $\mathrm{P}_{2} \mathrm{O}_{5}$ varlığı saptanmıștır.

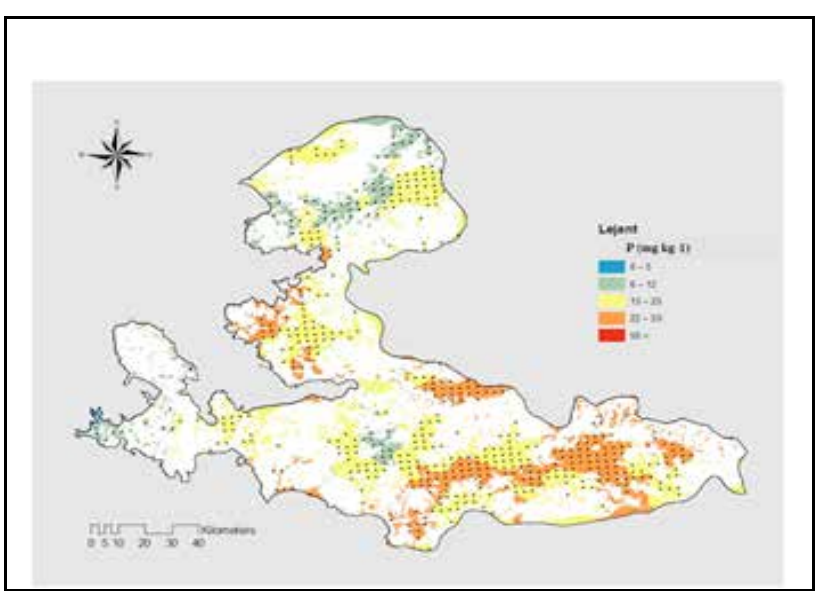

Șekil 10. İzmir ili tarım topraklarının alınabilir fosfor değerlerine ait değișim haritası

Figure 10. Change map of the available phosphorus levels of Izmir agricultural lands

Bitkiler tarafindan en çok alınan elementler arasında ikinci sırada yer alan potasyum, toprakta da en fazla bulunan bitki besin elementleri arasında yer alır ve yer kabuğunun yaklașık \%2.5'ini olușturur. Toprakların potasyum kapsamları, bünyelerine bağlı olarak geniș sınırlar arasında değișim göstermektedir. Kumtașı ve kuvarsit üzerinde olușan kaba bünyeli topraklarda yaklașık 20-25 kgda-1 $\mathrm{K}_{2} \mathrm{O}$ bulunmasına karșın, yüksek potasyum içeren kayalar üzerinde olușmuș ince bünyeli topraklarda 5000-6000 kgda ${ }^{1} \mathrm{~K}_{2} \mathrm{O}$ bulunabilmektedir. Potasyum, bitki büyümesi ve çoğalmasını sürdürmek için intiyaç duyulan hemen hemen tüm süreçlerde gereklidir. Ayrıca, büyüyen bitkilerin genel sağlığını iyileștirdiğinden ve hastalıklara karșı savașmalarına yardımcı olduğundan, "kaliteli" besin maddesi olarak bilinir. Araștırma alanı topraklarında bitkiler tarafından alınabilir K $30.10-2666.20 \mathrm{mgkg}^{-1}$ arasında değișmekte olup, toprakların \%47.21'inde K'nın olduğu bulunmuștur (Șekil 11). Topraksu (1983)'e göre İzmir ili tarım topraklarının \%31.8'inde $\mathrm{K}_{2} \mathrm{O}$ az,
$\% 16.5$ 'inde orta, \%8.1'inde yeter, \%43.6'sında ise yüksek $\mathrm{K}_{2} \mathrm{O}$ varlığı saptanmıștır.

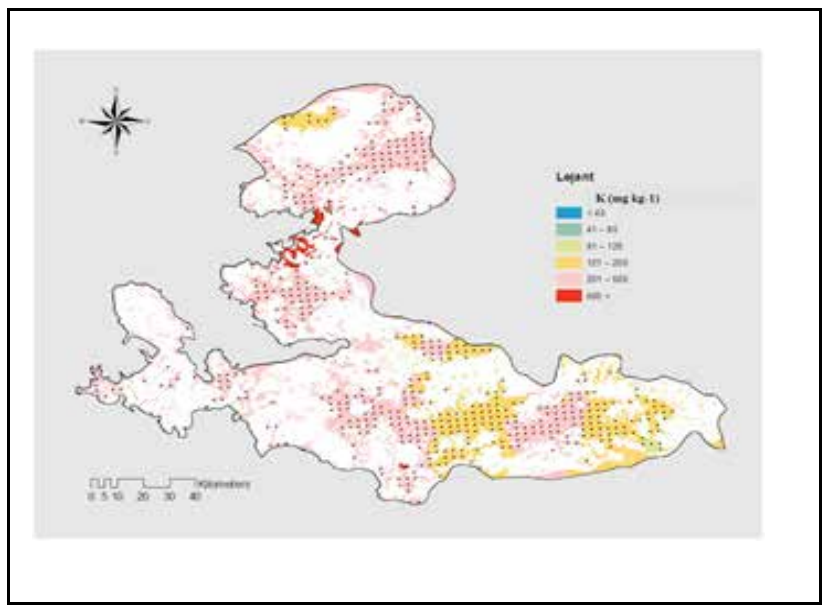

Șekil 11. İzmir ili tarım topraklarının alınabilir potasyum değerlerine ait değișim haritası

Figure 11. Change map of the available potassium levels of izmir agricultural lands

Mikro elementler, gerek topraklarda gerekse bitkilerde çok küçük miktarlarda bulunurlar, varlıkları ancak milyonda kısım olarak (ppm) ifade edilebilir. Topraktaki yarayıșlı ve bitkideki miktarları çok düșük olmalarına rağmen eksiklikleri söz konusu ise tarımsal üretimin düșmesine yol açarlar. Bitkisel üretimle, topraktan bir yılda sömürülen mikro element miktarı, topraktaki toplam mikro element miktarının çok küçük bir kısmını olușturur. Bu oran \% l'den daha azdır. Bitkilerde çok yoğun olarak mikro element eksiklik belirtileri görüldüğü durumlarda bile topraktaki toplam mikro element miktarları oldukça yüksek ve bitki gereksiniminin üzerindedir. Tarım topraklarında, toplam mikroelement eksikliğinden kaynaklanan ve temel eksiklik diye tanımlanan eksikliğe pek rastlanmaz, ancak, yıkanmanın çok ciddi boyutlarda görüldüğü kumlu topraklarda ve bazı peat topraklarda bu durum görülebilir (Eyüpoğlu vd., 1996).

Topraklarda Fe, genelde yüzeyde oksit ve hidrooksitleri șeklinde bulunur. Fakat toprağın organik madde bölümünde genelde șelatları șeklinde bulunur. Hem mineral ve hemde Fe'nin organik bileșikleri toprakta kolayca dönüșür ve organik madde Fe oksitlerin olușumu üzerine etkileyici rolü vardır. Araștırma alanı topraklarının analiz sonuçlarına göre ekstrakte edilebilir Fe miktarı 2.04-269.70 $\mathrm{mgkg}^{-1}$ arasında değișmekte olup, toprakların \%90.84'ünde Fe'in yüksek düzeyde olduğu belirlenmiștir (Șekil 12). Eyüpoğlu vd. (1996), Türkiye topraklarının bitkiye yarayıșlı bazı mikro 
elementler bakımından genel durumunu belirlemek üzere yaptıkları çalıșmada İzmir ili topraklarının \%20 .51 'inde <4.5 mgkg-1, \%30.77'sini 4.5-9 mgkg-1, \%48.72'sini ise >9 $\mathrm{mgkg}^{-1}$ değerlerinde bulmușlardır.

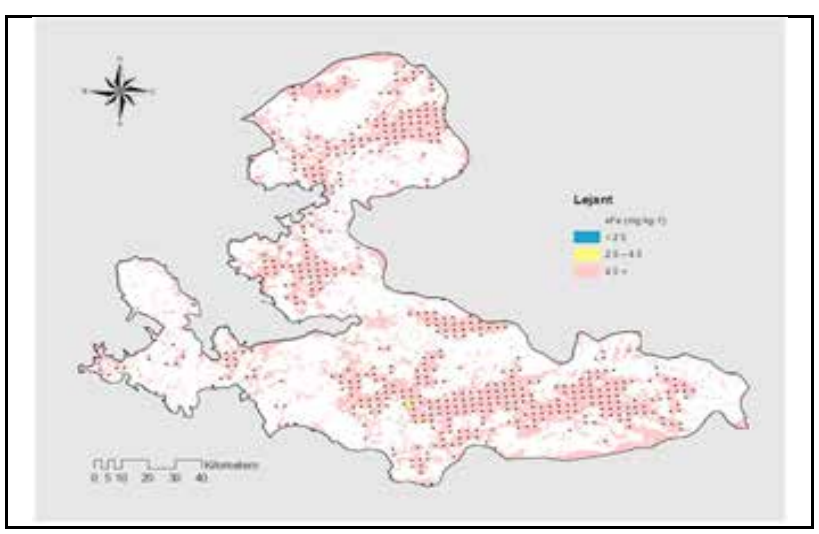

Șekil 12. İzmir ili tarım topraklarının ekstrakte edilebilir demir değerlerine ait değișim haritası

Figure 12. Change map of the extractable iron levels of izmir agricultural lands

Bakır toprakta en az mobil ağır metal olmasına rağmen, bu metal toprağın tüm tip çözeltilerinde, kompleksleșmiș iyonlar șeklinde ve serbest olarak çok bulunan bir metaldir. Araștırma alanı topraklarının analiz sonuçlarına göre ekstrakte edilebilir Cu miktarı $0.01-30.20 \mathrm{mgkg}^{-1}$ arasında değișmekte olup, toprakların \%69.92'sinde Cu'nun orta düzeyde olduğu belirlenmiștir (Șekil 13). Eyüpoğlu vd. (1996), Türkiye topraklarının bitkiye yarayıșlı bazı mikro elementler bakımından genel durumunu belirlemek üzere yaptıkları çalıșmada İzmir ili topraklarının \%20.51'inde 0.8-1.0 mgkg-1, \%35.90'ında $1.0-1.6 \mathrm{mgkg}^{-1}, \% 17.95^{\prime}$ inde ise $1.6-$ $2.2 \mathrm{mgkg}^{-1}$ arasında belirlenmiștir.

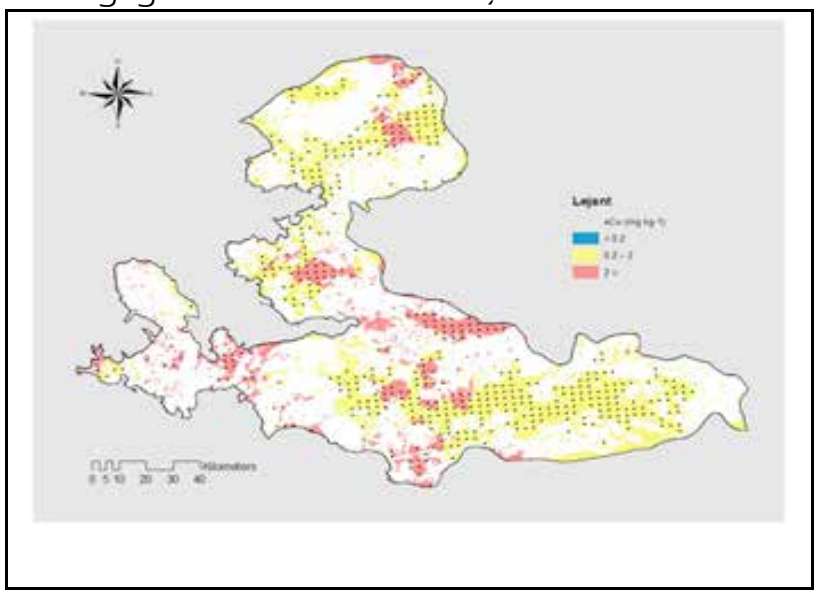

Șekil 13. İzmir ili tarım topraklarının ekstrakte edilebilir bakır değerlerine ait değișim haritası

Figure 13. Change map of the extractable copper levels of izmir agricultural lands
Çinko ZnS șeklindedir. Fakat silikatlarda $\mathrm{Mg}^{2+}$ ile yer değiștirdiği bilinir. Havalanma ișlemleri sırasında özellikle asit oksitleyici çevrelerde Zn mineralinin çözünmesiyle mobile $\mathrm{Zn}^{2+}$ olușur. Fakat Zn mineral ve organik maddelerce kolayca adsorbe olur ve böylece tüm toprak çeșitlerinde yüzeyde Zn birikimi gözlenir (Bakırcıoğlu 2009). Araștırma alanı topraklarının analiz sonuçlarına göre ekstrakte edilebilir Zn miktarı 0.07-19.14 $\mathrm{mgkg}^{-1}$ arasında değișmekte olup, toprakların \%44.42'sinde Zn'nin orta düzeyde olduğu saptanmıștır (Șekil 14). Eyüpoğlu vd. (1996), Türkiye topraklarının bitkiye yarayıșlı bazı mikro elementler bakımından genel durumunu belirlemek üzere yaptıkları çalıșmada Izmir ili topraklarının \%61.54'ünde $<0.5$ $\mathrm{mgkg}^{-1}, \% 30.77$ 'sinde ise $0.5-1.0 \mathrm{mgkg}^{-1}$ arasında bulunmuștur.

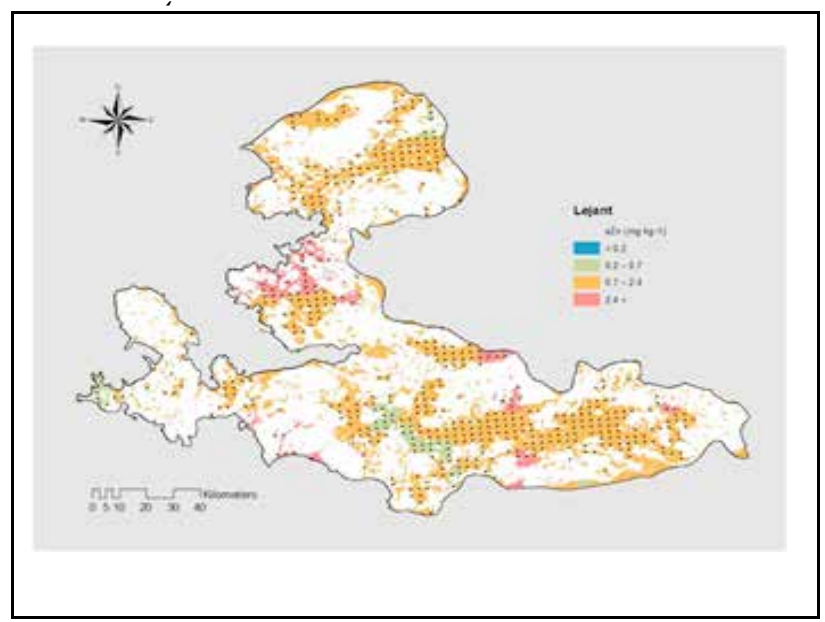

Șekil 14. İzmir ili tarım topraklarının ekstrakte edilebilir çinko değerlerine ait değișim haritası

Figure 14. Change map of the extractable zinc levels of izmir agricultural lands

Mangan, toprak çözeltilerinde çok sayıda basit ve kompleks iyonları șeklinde olabilir. Bütün Mn bileșikleri toprak için önemlidir. Araștırma alanı topraklarının analiz sonuçlarına göre ekstrakte edilebilir Mn miktarı 2.20-299.60 $\mathrm{mgkg}^{-1}$ arasında değișmekte olup, toprakların \%96.61'inde Mn'nin yüksek düzeyde olduğu tespit edilmiștir (Șekil 15). Eyüpoğlu vd. (1996), Türkiye topraklarının bitkiye yarayıșlı bazı mikro elementler bakımından genel durumunu belirlemek üzere yaptıkları çalıșmada İmir ili topraklarının \%15.37'sinde 5-10 mgkg ${ }^{-1}$, $\% 53.81$ 'inde $10-20 \mathrm{mgkg}^{-1}$ \%30.82'sinde ise >20.0 $\mathrm{mgkg}^{-1}$ değerlerinde belirlenmiștir. 


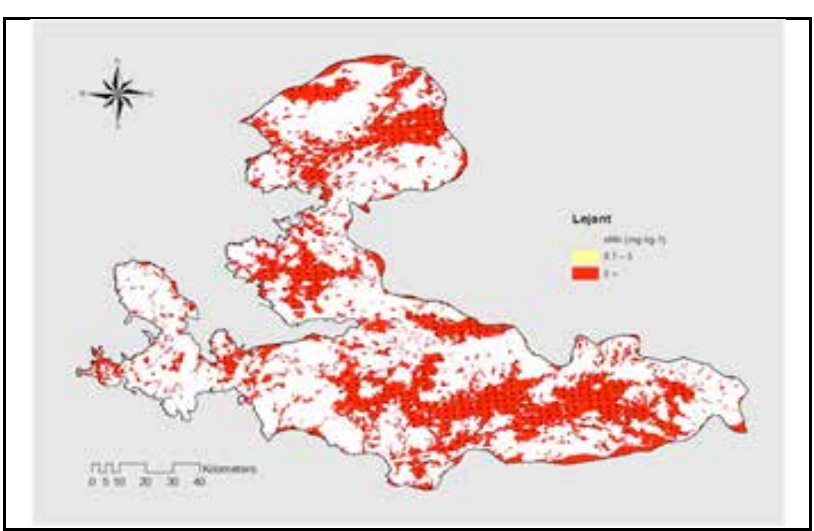

Șekil 15. İzmir ili tarım topraklarının ekstrakte edilebilir mangan değerlerine ait değișim haritası

Figure 15. Change map of the extractable manganese levels of Izmir agricultural lands

\section{SONUCLLAR}

Toprak, insanoğlunun sahip olduğu en önemli varlıkların bașında gelmektedir. Tarımsal üretimin temeli topraktır. Hayvansal ve bitkisel üretimi olușturan tüm maddeler topraktan sağlanır. Tarımda istenilen miktar ve kalitede ürünün elde edilmesinin birinci șartı, toprak verimliliğinin arttırımasıdır. Toprak verimliliğini arttırmada en önemli faktörlerden biri ise bitki besin elementleridir. Gübreleme amacıyla tarım alanlarına uygulanan bitki besin maddeleri, doğru yöntemlerle ve yeterli miktarlarda uygulandıkları takdirde toprak kirliliğine neden olmazlar. Ancak, bitki intiyacının çok üzerinde uygulanan ve topraktan kolayca uzaklaștırılamayan bazı besin maddeleri, diğer besin maddelerinin alınmasını engelledikleri için kirletici unsur olabilirler. Ülkemiz genelinde, ekonomik anlamda tarımsal üretimin yapııdığı yörelerde așırı ve bilinçsiz gübreleme uygulaması yanında, $N, P$ ve $K$ gübrelemesine dayalı tek yönlü gübreleme, toprakta ve bitkide mikro besin maddesi açlıklarının yaygınlașmasına neden olmaktadır. Bu nedenle toprakların özelliklerini saptamadan yapılan tarımdan büyük fayda sağlanamaz. Tarımın ve sanayiinin bașarılı olması veya geleceğe yönelik planlamaların doğru yapıllabilmesi için ilk önce eldeki materyalin çok iyi tanınması gerekmektedir. Sonuçta bu araștırma, İzmir ili tarım topraklarının özelliklerinin iyi tanınması, tarımın ve gerektirdiği girdilerin planlanmasında büyük fayda sağlayacaktır. Ayrıca, elde edilen haritalar incelenen parametreler yönünden bölgenin genel özellikleri hakkında bilgi niteliğinde olup, yapılacak diğer araștırmalara önemli ön bilgi sağlayacak ve model olușturacaktır.

\section{KAYNAKLAR}

Altınbaș Ü, Çengel M, Uysal H, Okur B, Okur B, Kurucu Y, Delibacak S (2004). Toprak bilimi. Ege Üniversitesi Ziraat Fakültesi Yayınları No: 557, İzmir.

Bakırcıoğlu D (2009). Toprakta makro ve mikro element tayini. Trakya Üniversitesi Fen Bilimleri Enstitüsü Kimya Anabilim Dall, Doktora Tezi, 134 sayfa.

Bouyoucos GJ (1951). A Recalibration of the hydrometer method for making mechanical analysis of soil. Agronomy Journal, 43: 434-438.

Çağlar KÖ (1949). Toprak bilgisi. Ankara: Ankara Üniversitesi, Ziraat Fakültesi Yayınları No: 10.

Çengel M (2006). Toprak mikrobiyolojisi. Ege Üniversitesi Ziraat Fakültesi Yayınları No: 558, İzmir.

Dengiz O, Özyazıı MA, Sağlam M (2015). Multi-criteria assessment and geostatistical approach for determination of rice growing suitability sites in Gokirmak catchment. Paddy and Water Environment, 13(1): 1-10.

Demircan M, Alan I, Șensoy S (2011). Coğrafi bilgi sistemleri kullanılarak sıcaklık haritalarının çözünürlüğünün artırıması, TMMOB Harita ve Kadastro Mühendisleri Odası 13. Türkiye Harita Bilimsel ve Teknik Kurultayı, 18-22 Nisan 2011, Ankara.

Doğan HM, Yılmaz DS ve Kilıç OM (2013). Orta Kelkit Havzası́nın bazı toprak özelliklerinin ters mesafe ağırlık yöntemi (IDW) ile haritalanması ve yorumlanması, Gaziosmanpașa Üniversitesi, Fen Bilimleri Enstitüsü, Gaziosmanpașa Bilimsel Araștırma Dergisi, Tokat.

Erșahin S (1999). Aluviyal bir tarlada bazı fiziksel ve kimyasal toprak özelliklerinin uzaysal (spatial) değișkenliğinin belirlenmesi. Selçuk Üniversitesi Ziraat Fakültesi Dergisi, 13(19): 34-41.

Eyüpoğlu F, Kurucu N, Talaz S (1996). Türkiye topraklarının bitkiye yarayıșlı bazı mikro elementler (Fe, Cu, Zn, Mn) bakımından genel durumu. T.C. Bașbakanlık Köy Hizmetleri Genel Müdürlüğü, Toprak ve Gübre Araștırma Enstitüsü Müdürlüğü, 72 s., Ankara.

Eyüpoğlu, F., 1999. Türkiye topraklarının verimlilik durumu. KHGM Toprak ve Gübre Araștırma Enstitüsü Yayını Teknik Yayın No: T-67, Genel Yayın No: 220 Ankara.

Korkmaz Bașel ED, Çakın K, Satman A (2008). Türkiye'nin yeraltı sıcaklık haritası ve tahmini ısı içeriği, VII. Ulusal Temiz Enerji Sempozyumu, İstanbul.

Loyd CD (2007). Local modelsfor spatial analysis, CRC Press, 21-22p.

Mulla DJ, AB McBratney (2001). Soil spatial variability, pp. 343-374. In A.W. Warrick (ed.). Soil Physics Companion. CRC Press. USA.

Nelson DW, Sommers LE (1982). Total carbon, organic carbon, organic matter. In: AL Madison, Editor. Methods of soil analysis part 2. Chemical and microbiological properties second edition. Wisconsin, USA: American Society of Agronomy Inc. pp. 539-579

Olsen SR, Cole CV, Watanabe FS, Dean LA (1954). Estimation of available phosphorus in soils by extraction with sodium bicarbonate. USDA Circular Nr 939, US Gov. Print. Office, Washington, D.C. 
Özten AF (2006). Dünya CBS günü, Yıldız Teknik Üniversitesi Oditoryumu Yıldız-Beșiktaș/İstanbul.

Özyazıcı MA, Özyazıcı G, Dengiz O (2011). Determination of micronutrients in tea plantations in The Eastern Black Sea Region, Turkey. African Journal of Agricultural Research, 6(22): 5174-5180.

Richards LA (1954). Diagnosis and Improvoment of saline and alkaline soils. U.S.A: U.S. Department of Agriculture, Handbook 60

Roberts JC (1979). Principles of land use planning ame, Soc. Agr., No: 21. (47)s.

Sağlam M (2008). Gökhöyük tarım ișletmesinde yaygın toprak serilerinde bazı kalite göstergelerinin uzaysal değișkenliğinin jeoistatistiksel yöntemlerle incelenmesi. Doktora tezi, Ankara Üniversitesi Fen Bilimleri Enstitüsü, Ankara.
Sağlam M (2013). Çok değișkenli istatistiksel yöntemler ile toprak özelliklerinin gruplandırıması. Toprak Su Dergisi, 2(1): 7-14.

Soil Survey Staff (1992). Procedures for collecting soil samples and methods of analysis for soil survey. Soil Survey Invest. Rep. I. U.S. Gov. Print. Office, Washington D.C.

Thompson, LM (1950). The mineralisation of organic phosphorus, nitrogen and carbon in virgin and cultivated soils. Ph.D. Thesis lowa State College.

Topraksu (1983). İzmir ili verimlilik envanteri ve gübre intiyaç raporu. Topraksu Genel Müdürlüğü yayınları. TOVEP yayın no: 09. Genel yayın no: 737.

Wilding LP (1985). Spatial variability: its documentation, accommodation and implication to soil surveys, pp. 166-194. In D.R. Nielsen and J. Bouma (eds.). Soil Spatial Variability: Pudoc, Wageningen, Netherlands. 